DOI: 10.22363/2313-0245-2018-22-3-265-271

\title{
DISTRUPTION OF SPERMATOGENESIS. MORPHOLOGICAL ASPECTS
}

\author{
N.G. Kulchenko
}

RUDN University, Moscow, Russia

\begin{abstract}
At the beginning of the 21st century there is a decline in quality of reproductive health of men around the world. In structure of sterile marriage the men's factor of infertility is found out in approximately $40-50 \%$ of cases. A little studied question of male infertility is the question of quantity and quality of gametes in convoluted seminiferous tubules. Aim: to study morphological (quantitative and qualitative) changes of a seminiferous epithelium of patients with male infertility. Materials and Methods: 264 patients with male infertility have been examined. Patients with an obstructive form of infertility, with diseases sexually transmitted, with varicocele, with the revealed genetic and immunological factors of infertility have not been included in the research. Patients with a heavy form of pathospermia $(n=112)$ were taken a testis biopsy before the ICSI cycle (Intra Cytoplasmic Sperm Injection). Further a condition of the seminiferous epithelium of a testis was estimated with the use of light microscopy. Results: Hypoplasy of a seminiferous epithelium was revealed around 34 (30,5\%) men, subtotal aplasia of a seminiferous epithelium - around 59 (52,6\%) patients, Sertoli Cell-only syndrome - around $12(10,7 \%)$ and tubular atrophy of convoluted seminiferous tubules - around 7 (6,2\%) patients. Conclusions: The morphological research of testis gives the opportunity to define the extent of pathological process at all stages of a spermatogenesis. Only on the basis of studying of features of a spermatogenesis of the specific patient it is possible to make an algorithm of further personal medical and rehabilitation actions.
\end{abstract}

Key words: male infertility, spermatogenesis, assisted reproductive technologies, azoospermia, Sertoli Cell-only syndrome

Correspondence Author:

N.G. Kulchenko, MD, urologist, doctor of ultrasonic diagnostics, Senior Lectures of the Department of Histology, Cytology and Embryology of the Medical Institute, RUDN University, ul. Miklukho-Maklay, 6, Moscow, 117198, Russia. E-mail: kle-kni@mail.ru; SPIN code: 1899-7871: ORCID 0000-0002-4468-3670.

Для цитирования: Кульченко Н.Г. Нарушение сперматогенеза. Морфологические аспекты // Вестник Российского университета дружбы народов. Серия: Медицина. 2018. Т. 22. № 3. С. 265-271. DOI: 10.22363/2313-0245-2018-22-3265-271.

For citation: Kulchenko N.G. (2018). Distruption of spermatogenesis. Morphological aspects. RUDN Journal of Medicine, 22 (3), 265-271. DOI: 10.22363/2313-0245-2018-22-3-265-271.

At the beginning of the 21 st century there is a decline of quality of reproductive health of men around the world $[1,2]$. Therefore male infertility is one of the main problems of Healthcare service worldwide $[3,4]$. In structure of sterile marriage the men's factor of infertility is found ou in approximately $40-50 \%$ of cases $[3,5,6]$. Male infertility - is a multifactorial disease $[1,5,7,8]$. The variety of the factors leading to infertility make imply difficulties to the choice of necessary methods of diagnostics and treatment [9-11]. According to modern authors, about $30 \%$ of the men who have asked for medical care concerning infertility have oligozoospermia or azoospermia of an unknown etiology [11, 12]. These patients are the most difficult in termes of diagnostics and treatment of patospermia. The testis biopsy is shown to this category of patients with the diagnostic and medical purpose $[13,14]$.

The morphological research of testis offers the opportunity to define the degree of manifastation of pathological process at all stages of spermatogenesis, to estimate condition of blood supply and 
structure of the interstitial cells which characterize an endocrine function of testis [15-17].

The introduction of the assisted reproductive technologies (ART) in clinical practice allows men to become the genetic father of the child even with severe damage of spermatogenesis $[3,7,18]$. However, the question of quantity and quality of gametes in convoluted seminiferous tubules in case of male infertility remains a little studied.

Aim: to study morphological changes of a seminiferous epithelium of patients with male infertility.

\section{MATERIALS AND METHODS}

264 patients aged from 18 to $46(34 \pm 8)$ years with complaints to absence of pregnancy and spouse more than 12 months have been examined. The criteria of inclusion of men in a research was: age of 18 years, an established fact of infertility without contraception during more than 1 year, absence of pathology from the sexual partner. Patients with an obstructive form of infertility, with diseases sexually transmitted, with the varikocele, with the revealed genetic and immunological factors of infertility, with the heavy accompanying pathology at the time of inspection haven't been included in research. The protocol of the real research has been approved by the decision of ethical committee of medical institute of RUDN (No. 7 from 9/22/2016) and also corresponds to the Declaration of Helsinki (WMA Declaration of Helsinki - Ethical Principles for Medical Research Involving Human Subjects, 64th WMA General Assambly, Fortaleza, Brazil, October 2013). The consent of patients to the research has been received.

The obligatory clinical trials of all patients were: medical history, general surveying, definition of a hormonal profile, double research of ejaculate (WHO, 2010).

All patients were taken a testis biopsy before the ICSI (Intra Cytoplasmic Sperm Injection). Tissue of testis was fixed in 10\% neutral formalin which was filled in paraffin blocks later. Histological slices were painted with hematoxylin and eosin. We studied microscope slides with the use of light microscope at amplification of $\times 400$ (lens $\times 40$, ocular $\times 10$ ). During microscopy we estimated the cross-sectional area of the convoluted seminiferous tubules (CST), total quantity of spermatogenous cells and their subpopulation structure at the rate on one CST (on strictly crossed slices of CST).

We treated the obtained digital data on the computer with the use of Statistica v. 6.0 program, at the same time we carried out comparison of average values of indicators during the one-factorial dispersive analysis with the subsequent paired comparisons. Statistically significant were distinctions at $\mathrm{p}<0,05$.

\section{RESULTS AND DISCUSSIONS}

The majority of the examined patients was older than 30 years $-71,2 \%$. This fact can be explained with the developed tendency of a delayed registration of marriage and the birth of children because of aspiration of the man first of all to get an education and to promote that is regarded as "late paternity" today. Distribution of the examined patients according age is presented in table 1 .

Among the patients of study group $(\mathrm{n}=264)$ primary infertility is recorded around 172 men $(65,2 \%)$, secondary infertility - around $92(34,8 \%)$. The average period of secondary infertility proceeded $54 \pm 18$ months. Distribution of patients on indicators of ejaculate is presented in figure 1 .

Table 1 / Таблица 1

Distribution of the examined patients according to the age /
Распределение исследуемых пациентов по возрасту
\begin{tabular}{|l|c|c|}
\hline \multicolumn{1}{|c|}{ Age / Возраст } & Quantity / Количество & $\%$ \\
\hline $20-25$ years & 13 & 4,9 \\
\hline $26-30$ years & 63 & 23,8 \\
\hline $31-35$ years & 104 & 39,6 \\
\hline 36-40 years & 60 & 22,7 \\
\hline Older than 40 years & 24 & 9,0 \\
\hline
\end{tabular}


Results of a morphological research of testis tissue / Результаты морфологического исследования ткани яичка

\begin{tabular}{|l|c|l|}
\hline $\begin{array}{c}\text { Type of morphological } \\
\text { changes }\end{array}$ & Number of patients (\%) & Characteristic of morphological changes in convoluted seminiferous tubules \\
\hline Hypospermatogenesis & $\begin{array}{c}34 \\
(30,5 \%)\end{array}$ & $\begin{array}{l}\text { The seminiferous epithelium is thinned, but differs in variety of celles: gonocytes, } \\
\text { spermatocytes of I and II, spermatids (the quantity is reduced), single spermato- } \\
\text { zoids can also be seen. There can be fragments of a desquamated seminiferous } \\
\text { epithelium in a lumen of the CST. Apexes of cytoplasm of Sertoli's cells reaching } \\
\text { the lumen of the CST are visible }\end{array}$ \\
\hline Germ cell aplasia subtotal & $\begin{array}{l}\text { Reduction of a seminiferous epithelium of different manifestication rates. Focal } \\
\text { remained gonocytes are well visible. Spermatid and a spermatocytes of I and II } \\
\text { are absent. Sertoli's cells are presented by the mature forms attached to a basal } \\
\text { membrane, they contain well expressed nucleus with clearly visible nucleoluses, } \\
\text { cells reach the lumen of the CST with their apexes. Vacuoles can be observed } \\
\text { in basal part of CST. There is a desquamated seminiferous epithelium in a lumen } \\
\text { of the CST (figure 2) }\end{array}$ \\
\hline Sertoli Cell-only syndrome & $\begin{array}{l}\text { Atrophy of a seminiferous epithelium. In a basal compartment only Sertoli's } \\
\text { cells of extended form and hypertrophied are visible, their cytoplasm may con- } \\
\text { tain vacuoles. Hialinnosis of the wall of convoluted seminiferous tubule (figure 3) }\end{array}$ \\
\hline Tubular atrophy & $\begin{array}{l}\text { Convoluted seminiferous tubules are deformed, narrowed (up to an obliteration), } \\
\text { lack of germ cells and somatic cells in them, expressed hialinnosis of a basal } \\
\text { membrane, hypotrophy of myoid cells (figure 4) }\end{array}$ \\
\hline
\end{tabular}



Fig. 1. Ejaculate indicators of examined patients /

Рис. 1. Показатели эякулята у обследованных больных

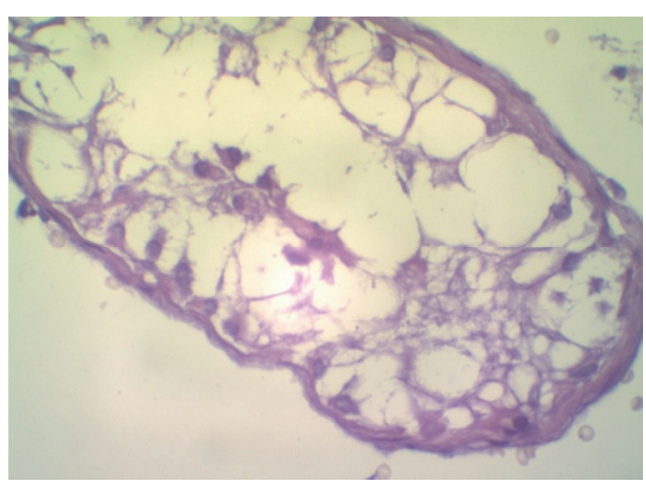

Fig. 3. Sertoli Cell-only syndrome Amplification $\times 400$. Colored with hematoxylin and eosin /

Рис. 3. Синдром «Только клетки Сертоли» Увеличение $\times 400$. Окраска гематоксилином и эозином



Fig. 2. Subtotal Germ cell aplasia Amplification $\times 400$. Colored with hematoxylin and eosin /

Pис. 2. Субтотальная аплазия мужских половых клеток Увеличение $\times 400$. Окраска гематоксилином и эозином



Fig. 4. Tubular atrophy

Amplification $\times 200$. Colored with hematoxylin and eosin /

Рис. 4. Тубулярная атрофия

Увеличение $\times 200$. Окраска гематоксилином и эозином 
Results of clinical trial of patients: clinical blood and urine analysis, the analysis of a secretion of a prostate, biochemical blood test, blood hormones, dab from an urethra on an infection, sexually transmitted haven't revealed pathological changes. All men denied past children's infections in the anamnesis, harmful factors on production. Therefore, all patients were diagnosed with idiopathic not obstructive male infertility.

Analyzing spermogram indicators, $112(42,4 \%)$ patients has been recorded with the severe form of infertility. To these men, according to indications, for the purpose of assessment of a spermatogenesis and a possibility of receiving sperm cells has been made the testis biopsy - micro TESE, with the subsequent morphological (qualitative and quantitative) assessment of bioptat.

During the histologic research of testis tissue we have received the following results: hypoplasy of a seminiferous epithelium was revealed around $34(30,5 \%)$ men, subtotal aplasia of a seminiferous epithelium — around 59 (52,6\%) patients, Sertoli Cell-only syndrome - around $12(10,7 \%)$ and tubular atrophy of convoluted seminiferous tubules around $7(6,2 \%)$ patients. Qualitative morphological features of disorder of spermatogenesis during male infertility are presented in the Table 2.

At hypoplasia of a seminiferous epithelium the following quantitative changes have been revealed: the area of CST was $47089 \pm 198 \mathrm{mkm}^{2}$, quantity of gonocytes - 30,9 $\pm 0,6$, spermatocytes I - 17,3 \pm $\pm 0,1$, there were no spermatocytes II and spermatids, there were $11 \pm 0,12$ Sertoli's cells.

At germ cell aplasia subtotal: the area of CST was - $25376 \pm 145 \mathrm{mkm}^{2}$, gonocytes - 11,6 \pm 0,9, there were no spermatocytes I, spermatocytes II and spermatids, there were $10 \pm 0,07$ Sertoli's cells.

$12(10,7 \%)$ patients have been stated with the Sertoli Cell-only syndrome: the area of CST was $9815 \pm 127 \mathrm{mkm}^{2}$, there were no gonocytes, spermatocytes I, spermatocytes II and spermatids, there were 7,4 $\pm 0,1$ Sertoli's cells.
During quantitative measurements of convoluted seminiferous tubules of patients with a tubular atrophy the area of CST was - $4603 \pm 83 \mathrm{mkm}^{2}$, in some sites up to a full obliteration of lumen, germ cells (gonocytes, spermatocytes I, spermatocytes II and spermatids) are absent, there is no Sertoli's cells.

Attracts attention that patients with an azoospermia have an area of CST and quantity of seminiferous cells authentically less, than patients with an oligoastenozoospermia $(\mathrm{p}<0,05)$. The quantity of Sertoli's cells at azoospermia is $16,3 \%$ less, than at oligoastenozoospermia $(\mathrm{p}<0,05)$.

Results of the conducted research allow to note that patients with severe disorder of spermatogenesis have a reduced area of CST, the quantity of gametes is also reduced. Cells of spermatogenesis are found only at hypoplasia of a seminiferous epithelium and at a subtotal germ cell aplasia subtotal that gives hope for a possibility of performance of correctional therapy.

The histologic research of tissue of testis is the main diagnostic method of male infertility allowing to allocate a group of patients with the possibility to use their own spermatozoids within the ART/ICSI programs. Patients with hypospermatogenesis need further treatment and correction of spermatogenesis with the subsequent extraction of germ cells for ICSI [19]. Men with the revealed subtotal aplasia of CST need additional diagnostics (genetic inspection, identification of local mutations), with the subsequent correction of spermatogenesis $[6,20]$. If the morphological diagnosis of Sertoli Cell-only syndrome, or tubular atrophy is revealed to the patient, then the further ART programs for the purpose of extraction of own spermatozoids will not be effective.

\section{CONCLUSION}

Studying of morphology of testis increases success of detection of mature gametes and the forecast of a reproductive reserve of testicles. Considering the recession of birth rate and the progress of male infertility, it is extremely important to approach 
diagnostics and treatment of a pathospermia individually. Only on the basis of studying of features of spermatogenesis of the specific patient it is possible to make an algorithm of further personal medical and rehabilitation actions. Coordinate work of versatile team of experts: urologists, andrologists, geneticists, morphologists, embryologists allows to do everything possible to receive biological posterity of men with infertility.

\section{REFERENCES}

1. Aktan G., Dogru-Abbasoglu S., Kucukgergin C. Mystery of idiopathic male infertility: is oxidative stress an actual risk? Fertil Steril 2013;99:1211-5.

2. Dohle G.R., Elzanaty S., van Casteren N.J. Testicular biopsy: clinical practice and interpretation. Asian $J$ Androl. 2012;14:88-93.

3. Ibtisham F., Wu J., Xiao M., An L.L., Banker Z., Nawab A., Zhao Y., Li G.H. Progress and future prospect of in vitro spermatogenesis. Oncotarget. 2017;8(39): $66709-66727$.

4. Kruglov D.P., Kostin A.A., Kaprin A.D., Semin A.V. Sotsialnye aspekty idiopaticheskogo besplodiya. Andrology and Genital Surgery. 2009;2:171-173. (In Russian).

5. Ramasamy R., Chiba K., Butler P., Lamb D.J. Male biological clock: a critical analysis of advanced paternal age. Fertil. Steril. 2015;103(6):1402-1406.

6. Kulchenko N.G., Myandina G.I., Alhedjoj Hasan. Assotiation-genetic study of polymorphism G-105A SEPS1 gene in male infertility. Research'n Practical Medicine Journal (Issled. prakt. med.). 2018; 5(2): 65-71 (In Russian).

7. Boitrelle F., Robin G., Marcelli F., Albert M., LeroyMartin B., Dewailly D. A predictive score for testicular sperm extraction quality and surgical ICSI outcome in non-obstructive azoospermia: a retrospective study. Human reproduction. 2011;26:3215-3221.

8. Kirby E.W., Wiener L.E., Rajanahally S., Crowell K., Coward R.M. Undergoing varicocele repair before assisted reproduction improves pregnancy rate and live birth rate in azoospermic and oligospermic men with a varicocele: a systematic review and meta-analysis. Fertil Steril. 2016;106:1338-1343.

9. Vloeberghs V., Verheyen G., Haentjens P., Goossens A., Polyzos N.P., Tournaye H. How successful is TESE-ICSI in couples with non-obstructive azoospermia? Human Reproduction. 2015;30(8):1790-1796.

10. Gromov A.I., Builov V.M. Radiation diagnostics and therapy in urology. Moscow: "GEOTAR-Media" Publ., 2011, 544 p. (In Russian).

11. Kraft K.H., Canning D.A., Snyder Iii H.M., Kolon T.F. Undescended Testis Histology Correlation with Adult Hormone Levels and Semen Analysis. The Journal of Urology. 2012;188(4):1429-1435.

12. Gonzalez-Marin C., Gosalvez J., Roy R. Types, causes, detection and repair of DNA fragmentation in animal and human sperm cells. Int J Mol Sci. 2012;13:14026-14052.

13. Kulchenko N.G. Oksidativnyj stress v razvitii neobstruktivnoj azoospermii. Difficult patient. 2017;15(4-5):4446. (In Russian)

14. Mruk D.D., Cheng C.Y. Sertoli-Sertoli and Sertoli-germ cell interactions and their significance in germ cell movement in the seminiferous epithelium during spermatogenesis. Endocrine Rev 2004; 25:747-806.

15. Modarresi T., Hosseinifar H., Daliri Hampa A. Predictive factors of successful microdissection testicular sperm extraction in patients with presumed sertoli cell-only syndrome. Int J Fertil Steril. 2015;9(1):107-112.

16. Hussein A. Evaluation of diagnostic testis biopsy and the repetition of testicular sperm extraction surgeries in infertility patients. Fertility and sterility. 2013;100(1):88-93.

17. Johnson K.J. Testicular histopathology associated with disruption of the Sertoli cell cytoskeleton. Spermatogenesis. 2014;4:e979106.

18. Berookhim B.M., Palermo G.D., Zaninovic N., Rosenwaks Z., Schlegel P.N. Microdissection testicular sperm extraction in men with Sertoli cell-only testicular histology. Fertil Steril. 2014;102(5):1282-1286.

19. Abdel Raheem A., Garaffa G., Rushwan N. Testicular histopathology as a predictor of a positive sperm retrieval in men with non-obstructive azoospermia. BJU Int. 2013;111(3):492-499.

20. Stouffs K., Gheldof A., Tournaye H. Sertoli Cell-Only Syndrome: Behind the Genetic Scenes. Biomed Res Int. 2016;2016:6191307.
Received 27.06.2018

Accepted 29.08.2018 
DOI: 10.22363/2313-0245-2018-22-3-265-271

\title{
НАРУШЕНИЕ СПЕРМАТОГЕНЕЗА. МОРФОЛОГИЧЕСКИЕ АСПЕКТЫ
}

\author{
Н.Г. Кульченко \\ Федеральное государственное автономное образовательное учреждение высшего образования \\ «Российский университет дружбы народов», г. Москва, Россия
}

В начале 21 века во всем мире происходит снижение качества репродуктивного здоровья мужчин. В структуре бесплодного брака мужской фактор бесплодия встречается примерно в $40-50 \%$ случаев. Мало изученным остается вопрос при мужском бесплодии о количестве и качестве половых клеток в извитых семенных канальцах. Цель: изучить морфологические (количественные и качественные) изменения сперматогенного эпителия у пациентов с мужским бесплодием. Материалы и методы: были обследованы 264 пациента с мужским бесплодием. В исследование не включали пациентов с обструктивной формой бесплодия, с заболеваниями, передающимися половым путем, с варикоцеле, с выявленными генетическими и иммунологическими факторами бесплодия. Пациентам с тяжелой патоспермией ( $\mathrm{n}=112)$ перед циклом ICSI (Intra Cytoplasmic Sperm Injection) выполнялась биопсия яичка. Далее оценивали состояние сперматогенного эпителия яичка с помощью световой микроскопии. Результаты. У 34 (30,5\%) мужчин выявлена гипоплазия сперматогенного эпителия, у 59 (52,6\%) пациентов - субтотальная аплазия сперматогенного эпителия, синдром «только клетки Сертоли» - 12 (10,7\%) и тубулярная атрофия извитых семенных канальцев - 7 (6,2\%). Выводы: Морфологическое исследование яичка дает возможность определить степень патологического процесса на всех стадиях сперматогенеза. Только на основании изучения особенностей сперматогенеза конкретного больного можно составить алгоритм дальнейших персональных лечебных и реабилитационных мероприятий.

Ключевые слова: мужское бесплодие, сперматогенез, вспомогательные репродуктивные технологии, азооспермия, синдром «Только клетки Сертоли»

Ответственный за переписку:

Кульченко Нина Геннадьевна, кандидат медицинских наук, врач уролог, врач ультразвуковой диагностики, старший преподаватель кафедры гистологии, цитологии и эмбриологии Медицинского института Федерального государственного автономного образовательного учреждения высшего образования «Российский университет дружбы народов», ул. Миклухо-Маклая, д. 6, г. Москва, 117198, Россия. E-mail: kle-kni@mail.ru; SPIN код: 1899-7871; ORCID 0000-0002-4468-3670

\section{БИБЛИОГРАФИЧЕСКИЙ СПИСОК}

1. Aktan G., Dogru-Abbasoglu S., Kucukgergin C. Mystery of idiopathic male infertility: is oxidative stress an actual risk? Fertil Steril 2013;99:1211-5.

2. Dohle G.R., Elzanaty S., van Casteren N.J. Testicular biopsy: clinical practice and interpretation. Asian J Androl. 2012;14:88 - 93.

3. Ibtisham F., Wu J., Xiao M., An L.L., Banker Z., Nawab A., Zhao Y., Li G.H. Progress and future prospect of in vitro spermatogenesis. Oncotarget. 2017;8(39):66709—66727.

4. Круглов Д.П., Костин А.А., Каприн А.Д., Семин А.В. Социальные аспекты идиопатического бесплодия. Андрология и генитальная хирургия. 2009; 2:171-173.

5. Ramasamy R., Chiba K., Butler P., Lamb D.J. Male biological clock: a critical analysis of advanced paternal age. Fertil. Steril. 2015;103(6):1402-1406.

6. Кульченко Н.Г., Мяндина Г.И., Альхеджой Хасан. Генетическое ассоциативное исследование роли полиморфизма G-105A гена SEPS1 при мужском бесплодии. Исследования и практика в медицине. 2018; 5(2): 65-71.

7. Boitrelle F., Robin G., Marcelli F., Albert M., LeroyMartin B., Dewailly D. A predictive score for testicular sperm extraction quality and surgical ICSI outcome in non-obstructive azoospermia: a retrospective study. Human reproduction. 2011; 26:3215-3221.

8. Kirby E.W., Wiener L.E., Rajanahally S., Crowell K., Coward R.M. Undergoing varicocele repair before assisted reproduction improves pregnancy rate and live birth rate in azoospermic and oligospermic men with a varicocele: a systematic review and meta-analysis. Fertil Steril. 2016;106:1338-1343.

9. Vloeberghs V., Verheyen G., Haentjens P., Goossens A., Polyzos N.P., Tournaye H. How successful is TESE-ICSI in couples with non-obstructive azoospermia? Human Reproduction. 2015;30(8):1790-1796. 
10. Громов А.И., Буйлов В.М. Лучевая диагностика и терапия в урологии: национальное руководство. М.: ГЭОТАР-Медиа, 2011. 544 с.

11. Kraft K.H., Canning D.A., Snyder Iii H.M., Kolon T.F. Undescended Testis Histology Correlation with Adult Hormone Levels and Semen Analysis. The Journal of Urology. 2012;188(4):1429-1435.

12. Gonzalez-Marin C., Gosalvez J., Roy R. Types, causes, detection and repair of DNA fragmentation in animal and human sperm cells. Int J Mol Sci. 2012;13:1402614052.

13. Кульченко Н.Г. Оксидативный стресс в развитии необструктивной азооспермии. Трудный пациент. 2017;15(4-5):44-46.

14. Mruk D.D., Cheng C.Y. Sertoli-Sertoli and Sertoli-germ cell interactions and their significance in germ cell movement in the seminiferous epithelium during spermatogenesis. Endocrine Rev 2004; 25:747—806.

15. Modarresi T., Hosseinifar H., Daliri Hampa A. Predictive factors of successful microdissection testicular sperm extraction in patients with presumed sertoli cell-only syndrome. Int J Fertil Steril. 2015;9(1):107-112.

16. Hussein A. Evaluation of diagnostic testis biopsy and the repetition of testicular sperm extraction surgeries in infertility patients. Fertility and sterility. 2013;100(1): $88-93$.

17. Johnson K.J. Testicular histopathology associated with disruption of the Sertoli cell cytoskeleton. Spermatogenesis. 2014;4:e979106

18. Berookhim B.M., Palermo G.D., Zaninovic N., Rosenwaks Z., Schlegel P.N. Microdissection testicular sperm extraction in men with Sertoli cell-only testicular histology. Fertil Steril. 2014;102(5):1282-1286.

19. Abdel Raheem A., Garaffa G., Rushwan N. Testicular histopathology as a predictor of a positive sperm retrieval in men with non-obstructive azoospermia. BJU Int. 2013; 111(3):492-499.

20. Stouffs K., Gheldof A., Tournaye H. Sertoli Cell-Only Syndrome: Behind the Genetic Scenes. Biomed Res Int. 2016;2016:6191307. 